\title{
Opuntia ficus-indica Pruning Waste Recycling: Recovery and Characterization of Mucilage from Cladodes
}

\section{Silvia Procacci' ${ }^{1}$ Emanuel Bojórquez-Quintal ${ }^{2}$, Giovambattista Platamone ${ }^{3}$, Oliviero Maccioni ${ }^{1}$, Vania Lo Vecchio ${ }^{3}$, Vincenzo Morreale ${ }^{3}$, Chiara Alisi ${ }^{4}$, Roberto Balducchi ${ }^{1}$, Loretta Bacchetta ${ }^{*}$}

${ }^{1}$ ENEA Casaccia, Division Biotecnology and Agroindustry, Rome, Italy

${ }^{2}$ CONACYT-Laboratorio de Análisis y Diagnóstico del Patrimonio, El Colegio de Michoacán, La Piedad, Mexico

${ }^{3}$ Bioinagro srl Agrofoods and Biochemicals, Licata, Italy

${ }^{4}$ ENEA Casaccia, Division Protection and Enhancement of the Natural Capital, Rome, Italy

Email: *loretta.bacchetta@enea.it

How to cite this paper: Procacci, S., Bojórquez-Quintal, E., Platamone, G., Oliviero, M., Lo Vecchio, V., Morreale Vincenzo, Alisi, C., Balducchi, R. and Bacchetta L. (2021) Opuntia ficus-indica Pruning Waste Recycling: Recovery and Characterization of Mucilage from Cladodes. Natural Resources, 12, 91-107.

https://doi.org/10.4236/nr.2021.124008

Received: November 30, 2020

Accepted: April 17, 2021

Published: April 20, 2021

Copyright (๑) 2021 by author(s) and Scientific Research Publishing Inc. This work is licensed under the Creative Commons Attribution International License (CC BY 4.0).

http://creativecommons.org/licenses/by/4.0/ (c) (i) Open Access

\begin{abstract}
The present work focuses on the proximate physical and chemical profile of Opuntia ficus-indica mucilage, mechanically extracted from cladodes, a waste of pruning in traditional organic cactus pear orchards in Italy (San Cono, Sicily). The mechanical extraction increased the mucilage yield to $30 \%$ dry weight. Physical characterization concerns $\mathrm{pH}$, viscosity, free acidity and density, useful for emulsifying capacity. Spectrophotometric analysis was applied to assess total carbohydrates, proteins, uronic acids, total polyphenols content and antioxidant capacity. DART-MS and SEM-EDX were performed to evaluate functional mucilage components and relative amounts of minerals, respectively. From the main results Opuntia ficus-indica by-product, in addition to the preponderant total carbohydrates content, shows the high concentration in calcium and potassium and a fair amount of health-promoting phytochemicals, which make it a good candidate for the different type of industrial applications.
\end{abstract}

\section{Keywords}

Natural Hydrocolloid, Opuntia ficus-indica (L) Mill., DART-MS Analysis, Chemical Analysis, Mucilage Extraction, Cladodes

\section{Introduction}

Due to the increasing demand from different industries (oil, paper, pharmaceutical, textiles, food), global hydrocolloids market has been growing greatly in the 
last years, reaching $\$ 7.9$ billion in 2019 with a forecast value of US $\$ 8.5$ billion by 2022 [1]. Opuntia ficus-indica (OFI) mucilage is a natural polymer produced in mucilage cells of parenchyma, inside the tissues of different organs (fruits and cladodes) with the main role to retain water. OFI mucilage is a hetero-polysaccharide of high molecular weight $\left(2.3 \times 10^{4}-3 \times 10^{6} \mathrm{~g} \cdot \mathrm{mol}^{-1}\right)$ which consists mainly of six sugars (arabinose, galactose, rhamnose, xylose, uronic acid and galacturonic acid), proteins and biomolecules. Recently Elnaz Salehi et al. [2] described some current applications of OFI hydrocolloid in the food industry such as the use of mucilage as coating and edible film to extend the shelf life of agricultural products. Mucilage was also used to encapsulate functional biomolecules and plant pigments, using spray drier and other techniques, for example to obtain food supplements or dyes. Other studies demonstrated its use as new natural hydrocolloid in multipurpose industrial applications [3] [4] [5] [6]. Opuntia ficus-indica cladodes mucilage was also used as a flocculation agent to remove bacterial contamination [2]. Based on the available literature, chemical composition and properties of Opuntia ficus-indica mucilage from cladodes could vary, depending on season collection, age of the plant, growing conditions and different methods of extraction [2]. Furthermore, structural and chemical differences between functional components of OFI mucilage may be also attributed to ineffective purification methods and/or contamination with other compounds [7] [8]. In general, the process of extraction should guarantee bio-products with appropriate characteristics for industrial processing, such as cost-effective, readily accessible at industrial scale, high yield, ecofriendly (no solvents used). In particular, the use of cladodes (pads) as a raw material for colloid production, offers an interesting prospect, considering that they are usually pruning residues, available throughout the year. In Italy for instance, Sicily is the first cactus pear supplier (providing $90 \%$ of the national fruit production) with three main cultivars: cv yellow (Sulfarina), cv white (Muscaredda) and $\mathrm{cv}$ red (Sanguigna). Pruning in the specialized OFI orchards, products annually a range of 6 - 8 tons/hectare of cladodes and immature fruits, which is one of the main costs for farmers, and not easy to be disposed of. The possibility of recycling this biomass from waste into high added-value by-products implies not only a reduction of crop management costs, but it could generate income diversification for farmers. As underlined by the European Bioeconomy Strategy, this approach leads the way towards a more sustainable agriculture system able to strengthen the competitiveness of productive chains. The consequences could be more investments in skills, knowledge, innovations with important opportunities for new jobs and regional development in local rural economies (Cork 2.0 declaration, 2016) [9]. On these premises, the aim of our work, in collaboration with a local enterprise, was to exploit the possible industrial applications of OFI mucilage from cladodes, collected after pruning in organic specialized orchards of traditional Sicilian cultivation areas. Our main goal was to characterize the quality and the properties of OFI mucilage as a by-product to be used in 
food/cosmetic/pharmaceutical applications. Recently, Rocchetti et al. [10] provided an analytical study on the nutraceutical composition of cladodes from "Ficodindia di San Cono", protected by designation of origin (PDO). Their results showed this "by-product" as a rich source of bioactive compounds with health-promoting properties. Therefore the specific objectives of our work were: 1) to evaluate the proximate physical and chemical profile of soluble mucilage mechanically extracted; 2) to provide further information on chemical and functional components by using X-ray microanalysis, chromatographic and DART-MS techniques; 3) to review the most relevant mucilage industrial applications.

\section{Experimental}

\subsection{Materials and Methods}

Cladodes of Opuntia ficus-indica (L.) Mill. were collected in the first week of February 2019 at Bubbonia farm, in specialized orchards under certified organic management. The farm of about 120 hectares is located in the municipality of Mazzarino (Sicily, Italy). The cladodes, collected from the same plot of land, were chosen among those of one and two years old. After collection, pads were washed and sanitized with water and Sanilyte ${ }^{\circledR}$, a sanitizer based on hypochlorous acid at final concentration of $95 \mathrm{mg} \cdot \mathrm{L}^{-1}$ and an oxide reduction potential (ORP) of $+850 \mathrm{mV}$, through a mechanical washing line, to eliminate impurities and reduce bacterial load. The final concentration of free chlorine and the ORP of the washing water was measured respectively using the Hanna instrument photometer HI 83399 with the HI 93701-01 kit and the Hanna Instruments HI $98121 \mathrm{pH}$ meter. Following the regulatory limits established by the Food and Drug Administration (FDA), the concentrations of free chlorine and ORP in washing water were $60 \mathrm{mg} \cdot \mathrm{L}^{-1}$ at $\mathrm{pH} 6.5$ and $830 \mathrm{mV}$ respectively. After the washing phase, cladodes were processed in the extraction line, equipped by an industrial shredder with specific adaptations by industrial partners. The extraction line was previously sanitized by spraying Sanilyte at $200 \mathrm{mg} \cdot \mathrm{L}^{-1}$ to avoid mucilage contamination processes. The mucilage was obtained through a mechanical-physical process that allows the extrusion of mucilage from cladodes and its storage in 1000 liter tanks. Five-liter of the sample was bottled and shipped by courier to ENEA Laboratory of Bioproducts and Bioprocesses (PROBIO) in Casaccia Center (RM). The sample was thus aliquoted in $50 \mathrm{~mL}$ falcon tubes and stored at $-20^{\circ} \mathrm{C}$, while a part was freeze-dried (LIO SPDGT 5PASCAL, 230 volts, $1 \mathrm{ph}, 50 \mathrm{H} 2$ ) until stable weight.

\subsection{Chemicals and Reagents}

All chemicals were purchased from R\&M Chemicals (Essex. UK). 2,4,6-Tris (2-pyridyl)-s-triazine (TPTZ), and 2,2-diphenyl-1-picrylhydrazyl (DPPH. 90\%), Bovine Serum Albumine and Trolox

(6-hydroxy-2,5,7,8-tetramethylchroman-2-carboxylic acid) were purchased from 
the Fluka company (Switzerland). All standards were supplied by Sigma-Aldrich (St. Louis, MO, USA).

\subsection{Physical and Chemical Analysis}

The $\mathrm{pH}$ was determined using Hanna Instruments-HI5000 and free acidity was determined by automatic titration with $\mathrm{NaOH} 0.5 \mathrm{~N}$ (pH Burette 24 CRISON). Density was estimated with a glass pycnometer. Viscosity of samples (10\% solution in water) was measured with a calibrated Cannon-Fenske glass capillary viscometer (Cannon Instrument Co., State College, PA, USA). Phenol-sulfuric acid method was followed for total carbohydrate content, measured at $480 \mathrm{~nm}$ [11]. Briefly, $100 \mathrm{mg}$ of extract mucilage powder and $5 \mathrm{~mL}$ of $2.5 \mathrm{~N} \mathrm{HCl}$ were mixed in a test tube and placed in a water bath at $95^{\circ} \mathrm{C}$ for $3 \mathrm{~h}$. The solution was neutralized with sodium carbonate, diluted with $5 \mathrm{~mL}$ of water and centrifuged. The supernatant was brought to a volume of $100 \mathrm{~mL}$. Then, a portion of the sample $(0.1 \mathrm{~mL})$ was added to $1 \mathrm{~mL}$ of $5 \%$ phenol and $5 \mathrm{~mL}$ of concentrated sulfuric acid and placed in a water bath at $30^{\circ} \mathrm{C}$ for $20 \mathrm{~min}$. Finally, total carbohydrate content was determined by UV Vis spectrophotometer at a wavelength of $480 \mathrm{~nm}$ and quantified against a calibration curve using xylose as a standard. Total uronic acids were determined following the method described by [8]. Lowry method with slight modifications was used to determine total proteins [12]. Total polyphenol content was determined using Folin-Ciocalteu method [13]. An aliquot of $250 \mu \mathrm{L}$ of the extract ( $40 \mathrm{mg}$ in $1 \mathrm{ml}$ methanol 80\%) was mixed with $250 \mu \mathrm{L}$ of Folin-Ciocalteau reagent, which was previously diluted with double distilled water (1:10). The mixture was allowed to stand for 7 min, then $500 \mu \mathrm{L}$ of sodium carbonate ( $20 \%$ w/v) was added to the mixture. Finally, the mixture was allowed to stand in the dark for about $40 \mathrm{~min}$ and the absorbance (Abs) was measured at $725 \mathrm{~nm}$ against a blank solution $(250 \mu \mathrm{L}$ of water + reagent) using a UV/Visible spectrophotometer. All measurements were carried out in triplicate and results were expressed as milligram of gallic acid equivalent per gram of dry weight ( $\left.\mathrm{mg} \mathrm{GAE} \mathrm{g} \mathrm{dw}^{-1}\right)$. Antioxidant capacity was determined by DPPH method: $100 \mu \mathrm{L}$ of sample were added to $2.9 \mathrm{~mL}$ of $0.06 \mathrm{mM}$ DPPH solution. The triplicate samples were shaken in a vortex and kept in the dark for $60 \mathrm{~min}$, before reading the absorbance at $517 \mathrm{~nm}$. The results were expressed as milligram of Trolox equivalent per gram of dry weight $\left(\mu \mathrm{moli} \mathrm{TE} \mathrm{g} \mathrm{dw}^{-1}\right.$ ). The percentage of inhibition was obtained by interpolation of a calibration curve (Abs vs $\mu \mathrm{M}$ Trolox) [13]. Dry mass refers to the mass of residue present after drying in an oven at $105^{\circ} \mathrm{C}$ until the mass remains unchanged $(24 \mathrm{~h})$ while ash \% was determined by dry incineration in a Heraeus muffle at $550^{\circ} \mathrm{C}$ for $8 \mathrm{~h}$. Determination of the relative content of $\mathrm{Ca}, \mathrm{K}, \mathrm{P}, \mathrm{Mg}$, and $S$ was performed in a microscopy scanning (SEM) (JEOL, Japan; model JSM6390LV/LGS; software INCA ${ }^{\oplus}$ Suite 4.08) equipped with an energy dispersive electron probe X-ray system (EDX) (LK-IE250 Oxford INCA Energy 250) for qualitative and quantitative microanalysis. Briefly, $2.5 \mathrm{mg}$ of lyophilized mucilage extract was weighed; the powder was carefully mounted on metal stub 
using double-sided carbon tape prior to analysis by SEM-EDX. The EDX scan time was set for 70 seconds, scan surface covered an area of $3.01 \mathrm{~mm} \times 2.32$ $\mathrm{mm}$, and the scan energy was about $20 \mathrm{Kv}$.

\subsection{DART-MS Analysis}

Pure neutral sugars (sucrose, glucose, galactose, mannose, arabinose, xylose and rhamnose), uronic acids (galacturonic and glucoronic), polyphenolic antioxidants (p-coumaric acid, isorhamnetin, isoquercetin and hyperoside), aminoacids and OFI natural hydrocolloid were analyzed as solids. For each sample, a capillary tube was dipped into the standards and/or lyophilized mucilage and then the capillary tube was placed between the helium stream of the DART ion source and the vacuum interface to obtain mass spectra (MS). Each sample was detected at least three to five times for $1 \mathrm{~min}$. Mass analysis was carried out on a JMS-T100LP AccuTOF LC-PLUS spectrometer (JEOL, Tokyo, Japan) with an ion source DART SVP100, (Ionsense, Saugus, MA, USA). The DART ion source was operated with helium for analysis and nitrogen for the standard mode, gas temperature was $300^{\circ} \mathrm{C}$, inlet pressure was $0.55 \mathrm{MPa}$, and voltage was $\pm 600 \mathrm{~V}$ was used for the negative ion mode. The acquisition of the mass spectra was registered with the Mass Center System Version 1.5.0k software a mass range of $\mathrm{m} / \mathrm{z}$ 50 - $1000 \mathrm{Da}$ in negative mode.

\subsection{Statistical Analysis}

Statistical analyses were used to compare results obtained in the replicates and data were expressed as mean \pm standard deviation (SD). All analyses were performed by SPSS software. Using analysis of variance (ANOVA), differences among means were determined for significance at $\mathrm{P}<0.05$. The EDX microanalysis was evaluated by one-way variance analysis (Sigma Plot ver. 12.0, Software). All tests were performed in triplicate.

\section{Results and Discussion}

Environmental problems in agriculture/agro-industry could be reduced significantly if good waste management is employed. Implementation of this practice aims to prevent pollution and other environmental problems as well as to promote economic benefits, such as the conversion of wastes into by-products, and the reduction of waste treatment costs. The recovery, reuse, or recycling of wastes, such as pruning residues, for further utilization is therefore essential as they might be raw materials for the production of other valuable products. Opuntia ficus-indica (L) Mill. could represent a good example in this contest, being its cladodes a cheap source of bioactive compounds. Cladodes as raw material are regularly consumed as vegetables or forage ( $16 \%$ or $22 \%$ of productive lands respectively) in Mexico, while a growing consumption demand has been documented in the US and Canada [8]. In other countries such as Italy, the reuse and recycling of pads can be considered as income diversification for farmers. 
The pruning in Italian specialized orchards, including "scozzolatura" for the induction of additional fruit productions, make available cladodes or immature fruits, which may be precious raw material for high value bio-products. Opuntia ficus-indica natural colloid can be obtained from the matrix (cladodes or fruit peel), through maceration in water [8] or using different solvents [5], however other techniques can be adopted such as mechanical pressing or grinding [14]. In general, extraction yields are low $(\leq 2 \%)$ in fresh weight and close to $19 \%$ in dry weight [2]. In our work, the manufacturing process, which is based on a mechanical method, considerably increases the efficiency in OFI mucilage extraction, with a yield of more than $30 \%$ in dry weight. Furthermore, the effective work capacity of the mechanic extraction processes was $0.5-0.6$ tons/h. Monrroy et al. [11] reported a yield of approximately $24 \% \pm 1 \%$ from Opuntia cochenillifera fresh cladodes treated with thermal $\left(80^{\circ} \mathrm{C}\right.$ and $\left.44^{\circ} \mathrm{C}\right)$ process. Nevertheless, high temperature affects the properties of hydrocolloid such as the rheological performance, as reported by different authors [8]. Therefore, a mechanical extraction that works at low temperature offers some advantages, which include the reduction of processing times and energy consumption, furthermore this process avoids the use of harmful and expensive solvents and increases the extraction yields.

\subsection{Physical Proximate Characterization of OFI Hydrocolloid}

Table 1 reports physical properties of OFI mucilage extracted from cladodes. As expected, $\mathrm{pH}$ was subacid $(4.50 \pm 0.30)$, as a consequence of CAM-based diurnal and seasonal rhythm which characterizes this species. The $\mathrm{pH}$ value found in our samples was lower than reported that by Gebresamuel and Gebre-Mariam [15] for $O$. ficus-indica (5.5 - 6), but comparable to those reported for gum arabic (4.5 5.6), which is the most utilized type of gum in food and other industrial applications [16]. Similarly the free acidity of Sicilian mucilage was found $1.40 \pm 0.20$ g. $\mathrm{L}^{-1}$ tartaric acid equivalent. However these parameters may vary according to different collection time with the acidity higher in cladodes harvested during winter when compared to cactus harvested during the spring. This difference may be explained by the reduced exposure to daylight during winter, but also appears to be genotype dependent [17]. Among physical properties, viscosity is one of the desired quality parameters of excipients for applications in both food and pharmaceutical formulations, especially for liquid preparations. Viscosity was found $4.84 \pm 0.20 \mathrm{mPa} s$ in a solution of $10 \%$ in water; similar results were reported for $4 \%$ solution of arabic gum. The density of experimental samples was estimated $1.01 \pm 0.01\left(\mathrm{~g} \cdot \mathrm{cm}^{-3}\right)$, in agreement with other authors[15].

\subsection{Chemical Composition}

Carbohydrates are the most typical components of Opuntia ficus-indica natural mucilage in a range of $13 \%-64 \%$ [15]. We found a value of $53 \%$ total carbohydrates (Table 2). Elnaz Salehi et al. [2] suggested an approximately amount of 
Table 1. Color, pH, free acidity, viscosity and density of Opuntia ficus-indica mucilage.

\begin{tabular}{cc}
\hline Physical traits & Description or Mean value $\pm \mathrm{SD}$ \\
\hline Color & Yellow without chlorophyll \\
$\mathrm{pH}$ & $4.50 \pm 0.30$ \\
Free acidity $\left(\mathrm{g} \cdot \mathrm{L}^{-1}\right.$ tartaric acid eq.) & $1.40 \pm 0.20$ \\
Viscosity $(\mathrm{mPa} \mathrm{s})$ & $4.84 \pm 0.20$ \\
Density $\left(\mathrm{g} \cdot \mathrm{cm}^{-3}\right)$ & $1.01 \pm 0.01$ \\
\hline
\end{tabular}

Data are reported as mean \pm standard deviation $(n=3)$.

Table 2. Chemical characterization of Opuntia ficus-indica hydrocolloid.

\begin{tabular}{|c|c|}
\hline Chemical composition & Mean value \pm SD \\
\hline Total carbohydrates (mg eq xylose $\mathrm{g}^{-1} \mathrm{dw}$ ) & $532.06 \pm 0.33$ \\
\hline Total uronic acids (mg uronic acids $\mathrm{g}^{-1} \mathrm{dw}$ ) & $2.1 \pm 0.6$ \\
\hline Total proteins (mg eq ABS $\mathrm{g}^{-1} \mathrm{dw}$ ) & $24.54 \pm 15.00$ \\
\hline Total polyphenols (mg GAE g ${ }^{-1} \mathrm{dw}$ ) & $19.40 \pm 0.02$ \\
\hline Antioxidant capacity $\left(\mu \mathrm{mol} \mathrm{TE} \mathrm{g}^{-1} \mathrm{dw}\right)$ & $22.5 \pm 0.5$ \\
\hline Dry mass (\% fw) & $3.30 \pm 0.20$ \\
\hline Ash (\% dw) & $29.30 \pm 4.00$ \\
\hline
\end{tabular}

Data are reported as mean \pm standard deviation $(n=3)$.

90\% total carbohydrates with a structural sugar composition in arabinose, rhamnose, xylose, and galactose (in ratios of 1.0:1.7:2.5:4.1) [7]. Due to the high amount of galactose and xylose, the rhamnogalacturonan polysaccharide is categorized in the class of galactoxylan gum [2]. The wide range in carbohydrate determination is probably due to the different extraction methods in particular to low efficiency and accuracy of hydrolysis phase that could negatively affect the final results. Nevertheless the types and content of carbohydrates can vary with the season and the age of cladodes; Ribeiro et al. [18] found samples collected in summer characterized by a higher content of carbohydrates especially glucose, fructose, galactose, xylose, and arabinose, with the tertiary cladode (old cladode) characterized by a double content of sugar compared to quaternary cladodes (young cladodes). Among the most reactive polysaccharide components, uronic acids are able to determine some important characteristics of mucilage such as viscosity, the ability to incorporate water into tissues, the chelation of $\mathrm{Ca}^{2+}$ ions as well as $\mathrm{pH}$ conditions. Their amount in natural polymers is commonly considered to be a measure of their polyelectrolyte nature, being a critical factor in coagulation/flocculation processes. The uronic acids content determined spectrophotometrically in Sicilian samples was found $2.1 \pm 0.6 \mathrm{mg} \cdot \mathrm{g}^{-1}$ with a lower amount than those reported by other authors [19] [20]. Perhaps the decarboxylation process during hydrolysis may have negatively affected this analytical 
determination; on the other hand the mechanical process may not be so efficient to extract pectin components from the green chlorenchyma tissue of pads. In accordance with previous authors [2] [21], we found the mean value of total protein content $24.54 \pm 15.00 \mathrm{mg} \mathrm{ABS} \mathrm{g}{ }^{-1} \mathrm{dw}$. Proteins content is another important factor to determine mucilage functional properties. Interactions that occur between proteins and specific hydrophilic functional groups of polysaccharides, can indeed influence the film-forming ability, emulsifying and stabilizing capacities, as well as foaming properties. Lecaros [22] found mainly glutamine, leucine and lysine as major components of proteins. Table 2 reports also total polyphenols content and antioxidant activity of mucilage samples. Overall, present findings showed OFI as a species of valuable source of antioxidant molecules with health promoting properties [6] [10]. Recently Boutakiout et al. [23] analyzed the juice from centrifuged cladodes and confirmed the total polyphenols content as factor season dependent, in any case they documented an amount in antioxidant molecules higher than those reported for apple (296.3 \pm $6.4 \mu \mathrm{g}$ GAE), banana (90.4 $\pm 3.2 \mu \mathrm{g}$ GAE), pineapple $(94.3 \pm 1.5 \mu \mathrm{g} \mathrm{GAE})$ or strawberry $(160.0 \pm 1.2 \mu \mathrm{g} \mathrm{GAE})$. The total polyphenol content is strongly correlated with the antioxidant capacity against free radicals. In the present study total polyphenol content was found around $19.40 \pm 0.02 \mathrm{mg} \mathrm{GAE} \mathrm{g}^{-1}$ dry weight and the antioxidant capacity of $22.5 \pm 0.5 \mu \mathrm{mol} \mathrm{TE} \mathrm{g}^{-1}$. Rocchetti et al. [10] found a value of total polyphenol content around $2600 \mathrm{mg} \mathrm{GAE} / \mathrm{kg}$ fresh weight in cladodes of cactus pear from San Cono (Italy), which was comparable with those of other authors; the same samples possessed GAE values of $1040 \mathrm{mg} / \mathrm{kg}$ fresh weight considering DPPH radical scavenging. Therefore the antioxidant compounds mainly linked in the external green cells of pads (clorenchyma) [24], are lower in mucilage which belongs from the internal part (mucilaginous cells of the parenchyma); this is the reason why the methods of extraction, or the use of assisted extraction [8] may actively contribute to improve the quality of by-product. Total organic matter, ash and sediment (dry mass), were respectively $3.30 \% \pm 0.20 \% \mathrm{fw}$ and $29.30 \% \pm 4.00 \% \mathrm{fw}$. This value is considerably high in comparison to those reported for commercial gums like locus bean gum $(0.7 \%$ $1.5 \%)$, xanthan gum (1.5\%) and acacia gum (1.2\%) [2] with interesting implication of Opuntia as an important source of mineral nutrients that could be recycled and reused [25].

In this work, mineral composition of OFI mucilage powder was determined using energy dispersive X-rays spectroscopy, as reported in Table 3. The high content of carbon and oxygen indicates a mainly organic composition of samples. In percent, calcium $(\mathrm{Ca}, 4.85 \% \pm 0.13 \%)$ was the most abundant mineral in mucilage, followed by potassium $(\mathrm{K}, 3.84 \% \pm 1.22 \%)$. These results are in agreement with those reported for common commercial gums and with those reported for Opuntia spp freeze-dried mucilage [26] or cladodes flour [27]. Magnesium, phosphorus and sulfur macrominerals are also found, although in less quantity (Table 3 ). 
Table 3. Mineral microanalysis by energy dispersive X-rays spectroscopy.

\begin{tabular}{cc}
\hline Element content (\%) & Mean value \pm SD \\
\hline Carbon (C) & $39.4 \pm 1.6$ \\
Oxygen (O) & $48.46 \pm 3.10$ \\
Calcium (Ca) & $4.85 \pm 0.13$ \\
Potassium (K) & $3.84 \pm 1.22$ \\
Magnesium (Mg) & $0.88 \pm 0.05$ \\
Sulfur (S) & $0.27 \pm 0.03$ \\
Phosphorus (P) & $0.22 \pm 0.03$ \\
\hline
\end{tabular}

Data are reported as mean \pm standard deviation $(n=3)$.

Opuntia mucilage is a viscous substance containing negatively charged macromolecules, with an important role in its high retention capacity and regulation of water content during periods of prolonged drought; it also intervenes in regulation of plant calcium accumulation [28]. Calcium oxalate crystals and areas with high calcium content mainly occur in mucilage cells of cladode parenchyma. The complex formation between carboxylic acid groups and bivalent ions (mainly $\mathrm{Ca}^{2+}$ ) considerably increases the gum solution viscosity or establishment of gel in presence of sufficient interactions [8]. The high calcium content in Opuntia ficus-indica mucilage favors the gelation of pectins with positive potential applications in food industry. Potassium is not an element that binds organic molecules, and high levels are rare in many fresh foods. However, potassium has an important role in fluid balance and nerve transmission in human body [5]. Many foods including Opuntia (cladodes and tunas), have high levels of $\mathrm{K}$, therefore they could be a good natural source of this mineral. Furthermore, the presence of electrolytes in hydrocolloids can be useful in the flocculation of suspension formulations [11] [15].

\subsection{Identification of Organic Compounds by DART-MS}

Direct analysis in real time (DART) allows the rapid evaluation (10 to 15 seconds) of samples or objects in their native state in the open environment. Samples or large molecules can break down into characteristic small fragments in the DART source via pyrolysis, and the products are then detected by high-resolution mass spectrometry (MS) [29]. Here we applied DART-AccuTOF LC-PLUS to investigate different types of monosaccharides and other natural molecules in Opuntia mucilage freeze-dried without sample pretreatment. The molecular ions (adducts) of the standards are presented in Table 4.

DART mass spectrum of OFI mucilage at $300^{\circ} \mathrm{C}$ in negative ion mode is shown in Table 5 and Figure 1. The adduct of arabinose or xylose, due to loss of a water molecule, $\left[\mathrm{M}-\mathrm{H}_{2} \mathrm{O}\right]^{-}$ion with $\mathrm{m} / \mathrm{z} 132$, was the most abundant molecular ion, and the deprotonated hexose adduct, $[\mathrm{M}-\mathrm{H}]^{-}$ion with $\mathrm{m} / \mathrm{z} 179$ was the weakest ion in dart spectrum in negative mode. Other high intensity molecular 
Table 4. List of observed negative monomer and cluster ions detected in the standards analyzed in negative mode by DART-MS.

\begin{tabular}{|c|c|c|}
\hline Standard sample & Adduct ion & $\mathrm{m} / \mathrm{z}$ value \\
\hline \multicolumn{3}{|l|}{ Disaccharides } \\
\hline Sucrose $\left[\right.$ Glu+Fruc- $\left.\mathrm{H}_{2} \mathrm{O}\right]$ & {$\left[\mathrm{Hex}-\mathrm{H}-5 \mathrm{H}_{2} \mathrm{O}\right]^{-}$} & 89 \\
\hline \multirow[t]{2}{*}{ MW: 342} & {$\left[\mathrm{Hex}-\mathrm{H}-\mathrm{H}_{2} \mathrm{O}\right]^{-}$} & 161 \\
\hline & {$[\mathrm{Hex}-\mathrm{H}]^{-}$} & $179^{*}$ \\
\hline Sucrose $=\mathrm{M}$ & {$[\mathrm{M}-\mathrm{H}]^{-}$} & 341 \\
\hline \multirow[t]{2}{*}{ Glu or Fruc $=\mathrm{Hex}$} & {$[2 \mathrm{Hex}-\mathrm{H}]^{-}$} & 359 \\
\hline & {$\left[3 \mathrm{Hex}-\mathrm{H}-\mathrm{H}_{2} \mathrm{O}\right]^{-}$} & 521 \\
\hline \multicolumn{3}{|l|}{ Monosaccharides } \\
\hline Glucose, mannose, galactose & {$\left[\mathrm{M}-\mathrm{H}-5 \mathrm{H}_{2} \mathrm{O}\right]^{-}$} & 89 \\
\hline \multirow[t]{5}{*}{ MW: 180} & {$\left[\mathrm{M}-\mathrm{H}-\mathrm{H}_{2} \mathrm{O}\right]^{-}$} & 161 \\
\hline & {$[\mathrm{M}-\mathrm{H}]^{-}$} & 179 \\
\hline & {$[\mathrm{M}+\mathrm{Cl}]^{-}$} & 215 \\
\hline & {$[2 \mathrm{M}-\mathrm{H}]^{-}$} & $359^{*}$ \\
\hline & {$[3 \mathrm{M}-\mathrm{H}]^{-}$} & 539 \\
\hline Rhamnose & {$[\mathrm{M}-\mathrm{H}]^{-}$} & 163 \\
\hline \multirow[t]{2}{*}{ MW: 164} & {$\left[2 \mathrm{M}-\mathrm{H}-\mathrm{CH}_{3}-\mathrm{CHO}-\mathrm{CH}_{2} \mathrm{O}\right]^{-}$} & $253^{*}$ \\
\hline & {$[2 \mathrm{M}-\mathrm{H}]^{-}$} & 327 \\
\hline Xylose, arabinose & {$[\mathrm{M}-\mathrm{H}]^{-}$} & 149 \\
\hline \multirow[t]{2}{*}{ MW: 150} & {$[2 \mathrm{M}-\mathrm{H}]^{-}$} & $299^{*}$ \\
\hline & {$[3 \mathrm{M}-\mathrm{H}]^{-}$} & 449 \\
\hline \multicolumn{3}{|l|}{ Uronic acids } \\
\hline Galacturonic, glucoronic & {$\left[\mathrm{M}-\mathrm{H}-\mathrm{H}_{2} \mathrm{O}\right]^{-}$} & 175 \\
\hline \multirow[t]{2}{*}{ MW: 194} & {$[\mathrm{M}-\mathrm{H}]^{-}$} & 193 \\
\hline & {$[2 \mathrm{M}-\mathrm{H}]^{-}$} & $387^{*}$ \\
\hline \multicolumn{3}{|l|}{ Amino acids } \\
\hline Glutamic acid & {$\left[\mathrm{M}-\mathrm{H}-\mathrm{H}_{2} \mathrm{O}\right]^{-}$} & 128 \\
\hline \multirow[t]{4}{*}{ MW: 147} & {$[\mathrm{M}-\mathrm{H}]^{-}$} & $146^{*}$ \\
\hline & {$\left[2 \mathrm{M}-\mathrm{H}-\mathrm{H}_{2} \mathrm{O}-\mathrm{NH}_{3}\right]^{-}$or $\left[2 \mathrm{M}-\mathrm{H}-2 \mathrm{H}_{2} \mathrm{O}\right]^{-}$} & 257 \\
\hline & {$\left[2 \mathrm{M}-\mathrm{H}-\mathrm{H}_{2} \mathrm{O}\right]^{-}$} & 275 \\
\hline & {$[2 \mathrm{M}-\mathrm{H}]^{-}$} & 293 \\
\hline \multicolumn{3}{|l|}{ Polyphenolic antioxidants } \\
\hline P-coumaric acid & {$[\mathrm{M}-\mathrm{H}]^{-}$} & $163^{*}$ \\
\hline MW: 164 & {$[2 \mathrm{M}-\mathrm{H}]^{-}$} & 327 \\
\hline Isorhamnetin & {$[\mathrm{M}-3 \mathrm{H}]^{-}$} & 313 \\
\hline \multirow[t]{3}{*}{ MW: 316} & {$[\mathrm{M}-2 \mathrm{H}]^{-}$} & 314 \\
\hline & {$[\mathrm{M}-\mathrm{H}]^{-}$} & $315^{*}$ \\
\hline & {$[2 \mathrm{M}-\mathrm{H}]^{-}$} & 631 \\
\hline Isoquercetin ISOQ & {$\left[\mathrm{Glu}-\mathrm{H}-\mathrm{H}_{2} \mathrm{O}\right]^{-}$} & 161 \\
\hline ISOQ $=\mathrm{M}$ & {$[\mathrm{Q}-\mathrm{H}]^{-}$} & $301^{*}$ \\
\hline Quercetin + glucose $-\mathrm{H}_{2} \mathrm{O}$ & {$\left[\mathrm{Q}-\mathrm{H}+\mathrm{O}^{-}\right]^{-}$} & 317 \\
\hline$\left[\mathrm{Q}+\mathrm{Glu}-\mathrm{H}_{2} \mathrm{O}\right]$ & {$[\mathrm{M}-2 \mathrm{H}-\mathrm{OH}]^{-}$} & 445 \\
\hline \multirow[t]{3}{*}{ MW: 464} & {$[\mathrm{M}-3 \mathrm{H}]^{-}$} & 461 \\
\hline & {$[2 \mathrm{Q}-\mathrm{H}]^{-}$} & 603 \\
\hline & {$[2 \mathrm{Q}-\mathrm{H}+\mathrm{O}]^{-}$} & 619 \\
\hline Hyperoside Hyp & {$\left[\mathrm{Gal}-\mathrm{H}-\mathrm{H}_{2} \mathrm{O}\right]^{-}$} & 161 \\
\hline Hyp $=$ M & {$[\mathrm{Gal}-\mathrm{H}]^{-}$} & 179 \\
\hline Quercetin + galactose $-\mathrm{H}_{2} \mathrm{O}$ & {$[\mathrm{Q}-\mathrm{H}]^{-}$} & $301^{*}$ \\
\hline$\left[\mathrm{Q}+\mathrm{Gal}-\mathrm{H}_{2} \mathrm{O}\right]$ & {$\left[\mathrm{M}-3 \mathrm{H}+\mathrm{O}^{-}\right]^{-}$} & 477 \\
\hline MW: 464 & {$[2 \mathrm{Q}-\mathrm{H}]^{-}$} & 603 \\
\hline
\end{tabular}

* Most abundant ion. 
Table 5. Major fragments for monosaccharides generated in OFI mucilage extract (freeze-dried) by DART-MS and proposed chemical formulas.

\begin{tabular}{cccccc}
\hline Identification & {$[\mathrm{M}-\mathrm{H}]^{-}$} & {$[\mathrm{M}-\mathrm{H}+\mathrm{Cl}]^{-}$} & {$\left[\mathrm{M}-\mathrm{H}_{2} \mathrm{O}\right]^{-}$} & {$\left[\mathrm{M}-2 \mathrm{H}_{2} \mathrm{O}\right]^{-}$} & {$\left[\mathrm{M}-5 \mathrm{H}_{2} \mathrm{O}\right]^{-}$} \\
\hline Six-carbon & 179.0099 & $214.9824^{*}$ & & & 89.0010 \\
Five-carbon & & & $132.9862^{*}$ & 114.9734 & \\
* & & & & \\
${ }^{*}$ Most abundant ion & & & & \\
\hline
\end{tabular}

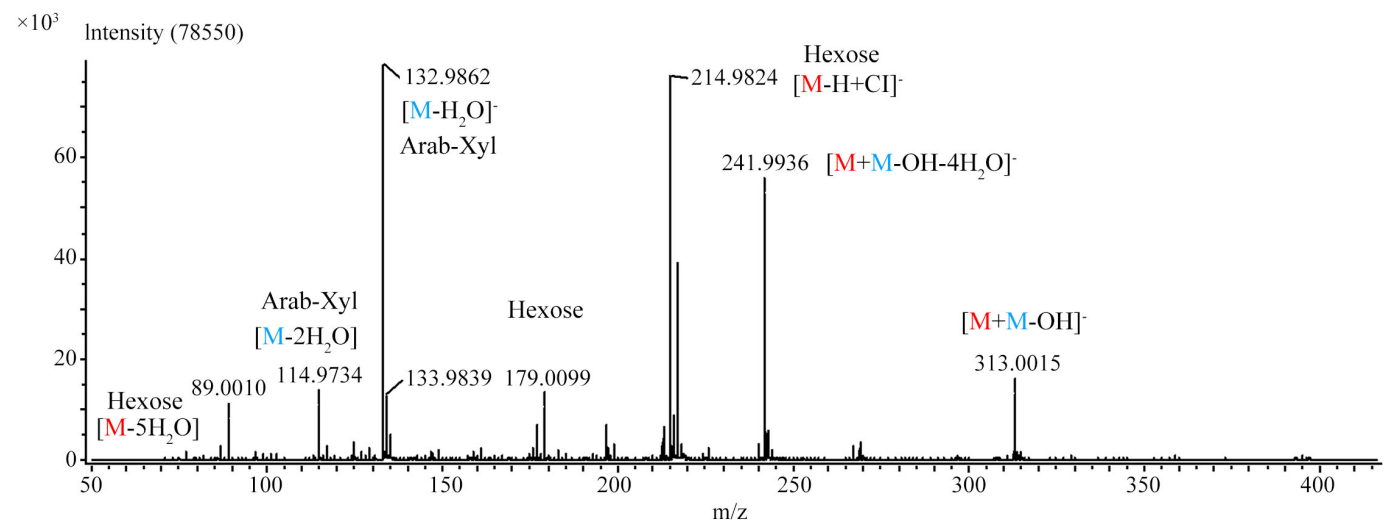

Figure 1. DART mass spectra of Opuntia ficus-indica mucilage extract with a heated argon gas temperature of $300^{\circ} \mathrm{C}$ in negative ion mode. The major molecular ions for five carbon ( $\mathrm{M}$ in blue) and six carbon $\left(\mathrm{M}\right.$ in red) monosaccharides are represented as adducts $\left[\mathrm{M}-\mathrm{nH}_{2} \mathrm{O}\right]^{-},[\mathrm{M}-\mathrm{H}]^{-},[\mathrm{M}-\mathrm{OH}]^{-},[\mathrm{M}-\mathrm{H}+\mathrm{Cl}]$-or $[\mathrm{M}$ $\left.+\mathrm{Cl}]^{-}.\right]^{-}$. The mass to charge ratio $(\mathrm{m} / \mathrm{z})$ of each anion is represented by the value of the peaks.

ions were $\mathrm{m} / \mathrm{z} 214$ and $\mathrm{m} / \mathrm{z} 215$, which correspond to the hexose adduct $[\mathrm{M}-\mathrm{H}+$ $\mathrm{Cl}]^{-}$and $[\mathrm{M}+\mathrm{Cl}]^{-}$that are formed by binding a chlorine ion to the hexoses as mentioned by [30]. Other monosaccharide adducts present in the DART-MS spectrum are the molecular ions $\mathrm{m} / \mathrm{z} 114$ and $\mathrm{m} / \mathrm{z}$ 89. These molecular ions correspond to the monosaccharide adduct of molecular weight 150 (arabinose and xylose) that lose two water molecules $\left[\mathrm{M}-2 \mathrm{H}_{2} \mathrm{O}\right]^{-}$, as well as the deprotonated adduct of hexoses without five $\mathrm{H}_{2} \mathrm{O}$ molecules $\left[\mathrm{M}-\mathrm{H}-5 \mathrm{H}_{2} \mathrm{O}\right.$ ], respectively. In MS-DART, polysaccharides undergo thermal decomposition during ambient ionization, generating characteristic fingerprints or profiles, consisting of smaller fragments [31] [32]. Many fingerprints corresponding to mono and oligosaccharides have been reported for standards and ginseng extracts [33], herbal extracts of traditional Chinese medicine [34], and glycosides of plants of biological importance activities [31]. These profiles or fingerprints of saccharides have been acquired in a negative and positive ion mode in DART. Analysis in positive mode is easy to identify monosaccharides as ammonium adducts $\left(\mathrm{NH}_{4}^{+}\right)$in DART spectra [33]; however, these ammoniated molecules (adducts) are weak or absent in plant extracts rich in oligosaccharides. In contrast, monosaccharides or oligosaccharides ions (de-protonation) and molecular ions (radical ions) were easily detected in negative DART mass spectra [33] [34]; such as the monosaccharide fingerprint of our natural hydrocolloid (Figure 1) [35] [36]. 
Table 6. Industrial applications of Opuntia ficus-indica mucilage.

\begin{tabular}{|c|c|c|}
\hline INDUSTRIAL SECTOR & APPLICATION/FUNCTION & REFERENCE \\
\hline \multirow{4}{*}{ FOOD } & $\begin{array}{l}\text { edible coating to extend the shelf life } \\
\text { of fruits and vegetables/edible films }\end{array}$ & [21] [37] [38] \\
\hline & $\begin{array}{l}\text { encapsulation agent to preserve bioactive } \\
\text { compounds, natural colorant (spray-drying } \\
\text { technique) }\end{array}$ & [2] [39] [40] \\
\hline & thickeners, stabilizers, gelling agents & [4] [19] [20] \\
\hline & gluten free ingredient & [27] \\
\hline WASTEWATER TREATMENT & $\begin{array}{l}\text { flocculation agent to remove bacterial } \\
\text { contamination, membranes used for removing } \\
\text { different heavy metals (spin nano- or } \\
\text { microfibers) }\end{array}$ & $\begin{array}{l}{[41][42]} \\
{[43][44]}\end{array}$ \\
\hline \multirow{2}{*}{$\begin{array}{l}\text { COSMETIC AND } \\
\text { PHARMACEUTICAL } \\
\text { INDUSTRIES }\end{array}$} & $\begin{array}{l}\text { gastroprotective effect, moisturizing, healing, } \\
\text { antioxidant }\end{array}$ & {$[5][6][45]$} \\
\hline & $\begin{array}{l}\text { pharmaceutical excipient: gelling agent for } \\
\text { sustained release drug delivery }\end{array}$ & {$[45]$} \\
\hline $\begin{array}{l}\text { CULTURAL } \\
\text { HERITAGE/CONSTRUNCTION }\end{array}$ & $\begin{array}{l}\text { thin layers paint consolidator and organic } \\
\text { additives to improve the properties of } \\
\text { bio-mortars }\end{array}$ & {$[46][47][48]$} \\
\hline AGRICULTURE & Soil improver & [49] \\
\hline
\end{tabular}

\subsection{Mucilage Potential Industrial Applications}

Cactus pear mucilage is an interesting functional biopolymer that may be used in food, cosmetic and pharmaceutical industries thanks to its physical and functional characteristics, such as: viscoelasticity (edible coating), ability to form a molecular network (retains water), ability to form films (filtration), etc. Table 6 is reported a list of possible industrial applications of the hydrocolloid, which gives evidence of its multi-functionality.

Besides the discussed uses in cosmetic/pharmaceutical/food industries, other productive chains may be explored. For instance within the Bilateral Cooperation Program between Italy and Mexico, ENEA and Colegio of Michoàcan, Colmich studied the application of mucilage as thin layers paint consolidator and organic additives to improve the properties of bio-mortars for restoration in cultural heritage. The encouraging results suggest its possible applications also in this niche economic sector [46]. Among research in progress the biodegradable and compostable plastics. Therefore a future technological challenge is the ability to optimize the extraction and purification techniques, drying, and other processing conditions to obtain different applications bioproducts.

\section{Conclusion}

In this work we demonstrate the physical and chemical properties of the hydrocolloid extracted mechanically from Opuntia ficus-indica pads pruned in organic specialized orchards. We also applied for the first time MS-DART, a particularly advantageous and rapid technique (10 - 15 seconds) for the analysis of 
small and large polysaccharides and other natural products, enriching the available data on Opuntia mucilage functional components. The results reveal that this by-product is characterized by high quality and is greatly attractive for different industrial applications, also considering the low cost and availability of the raw material. In spite of the growing interest in functional properties of OFI by-products, there is a lack of research and technology-driven industries to isolate and formulate new bio-products, starting from agro-food Opuntia waste [50]. Therefore in order to boost circular economy of cactus pear, the suppliers need new crop investments, more availability of green technologies and knowledge-based communication efforts, for consumer acceptance. This will lead to the transition towards model of industrial synergy, where groups of farms share resources and recycle waste, reducing costs and environmental impacts of the agro-productive chains [51].

\section{Acknowledgements}

With the contribution of the Ministry of Foreign Affairs and International Cooperation, Directorate-General for the promotion of the Country SystemScientific and Technological Bilateral Cooperation Project Italy-Mexico. The results of the present work are also the outputs of private research contract between Bioinagro S.r.l and ENEA, Bio-Agroindustry Division, Bioprocess and Bioproducts Laboratory. The authors thank Luis Rojas Abarca and Esteban Sanchez Rodriguez for their valuable technical support in MS-DART and SEM analysis and Antonella Serinelli for her precious help.

\section{Conflicts of Interest}

The authors declare no conflicts of interest regarding the publication of this paper.

\section{References}

[1] Market and Market (2018) Hydrocolloids Market by Type, Function, Source, Application, \& by Region Global Forecast to 2020.

https://www.marketsandmarkets.com/Market-Reports/hydrocolloid-market-1231.( $\underline{\mathrm{html}}$

[2] Salehi, E., Emam-Djomeh, Z., Fathi, M. and Askari, G. (2019) Opuntia ficus-indica Mucilage. In: Razavi, S.M.A., Ed., Emerging Natural Hydrocolloids, Wiley, Hoboken, Chapter 17, 425-444. https://doi.org/10.1002/9781119418511.ch17

[3] Sáenz, C., Estévez, A.M., Sepúlveda, E. and Mecklenburg, P. (1998) Cactus Pear Fruit: A New Source for a Natural Sweetener. Plant Foods for Human Nutrition, 52, 141-149. https://doi.org/10.1023/A:1008033704523

[4] El-Samahy, S.K., Youssef, K.M. and Moussa-Ayoub, T.E. (2009) Producing Ice Cream with Concentrated Cactus Pear Pulp: A Preliminary Study. Journal of the Professional Association for Cactus Development, 11, 1-12.

[5] Sáenz, C., Sepúlveda, E. and Matsuhiro, B. (2004) Opuntia Spp Mucilage’s: A Functional Component with Industrial Perspectives. Journal of Arid Environments, 57, 275-290. https://doi.org/10.1016/S0140-1963(03)00106-X 
[6] Inglese, P., Mondragon, C., Nefzaoui, A., Saenz, C., Louhaichi, M., Makkar, H. and Taguchi, M. (2017) Crop Ecology, Cultivation and Uses of Cactus Pear. Food and Agriculture Organization of the United Nations.

[7] Matsuhiro, B., Lillo, L.E., Saenz, C., Urzúa, C.C. and Zárate, O. (2006) Chemical Characterization of the Mucilage from Fruits of Opuntia ficus indica. Carbohyd Polym, 63, 263-267. https://doi.org/10.1016/j.carbpol.2005.08.062

[8] Bacchetta, L., Maccioni, O., Martina, V., Bojorquez-Quintal, E., Persia, F., Procacci, S. and Zaza, F. (2019) Quality by Design Approach to Optimize Cladodes Soluble Fiber Processing Extraction in Opuntia ficus-indica (L.) Miller. Journal of Food Science and Technology, 56, 3627-3634.

https://doi.org/10.1007/s13197-019-03794-7

[9] (2016) Cork 2.0 Declaration-A Better Life in Rural Areas. Publications Office of the European Union, Luxembourg.

[10] Rocchetti, G., Pellizzoni, M., Montesano, D. and Lucini, L. (2018) Italian Opuntia ficus-indica Cladodes as Rich Source of Bioactive Compounds with Health Promoting Properties. Foods, 7, 24. https://doi.org/10.3390/foods7020024

[11] Monrroy, M., Garcìa, E., Rìos, K. and Garcìa, J.R. (2017) Extraction and Physicochemical Characterization of Mucilage from Opuntia cochenillifera (L.) Miller. Journal of Chemistry, 2017, Article ID: 4301901. https://doi.org/10.1155/2017/4301901

[12] Lowry, O.H., Rosebrough, S., Farr, A.L. and Randall, R.J. (1951) Protein Measurement with the Phenol Reagent. Journal of Biological Chemistry, 193, 265-275. https://doi.org/10.1016/S0021-9258(19)52451-6

[13] Proestos, C., Lytoudi, K., Mavromelanidou, O.K., Zoumpoulakis, P. and Sinanoglou, V.J. (2013) Antioxidant Capacity of Selected Plant Extracts and Their Essential Oils. Antioxidants, 2, 11-22. https://doi.org/10.3390/antiox2010011

[14] Sepúlveda, E., Sáenz, C., Aliaga, E. and Aceituno, C. (2007) Extraction and Characterization of Mucilage in Opuntia spp. Journal of Arid Environments, 68, 534-545. https://doi.org/10.1016/j.jaridenv.2006.08.001

[15] Gebresamuel, N. and Gebre-Mariam, T. (2012) Comparative Physicochemical Characterization of the Mucilages of Two Cactus Pears (Opuntia spp.) Obtained from Mekelle, Northern Ethiopia. Journal of Biomaterials and Nanobiotechnology, 3, 79-86. https://doi.org/10.4236/jbnb.2012.31010

[16] Daoub, R.M.A., Elmubarak, A.H., Misran, M., Hassan, E.A. and Osma, M.E. (2016) Characterization and Functional Properties of Some Natural Acacia Gums. Journal of the Saudi Society of Agricultural Sciences, 17, 241-249.

https://doi.org/10.1016/j.jssas.2016.05.002

[17] Stintzing, F.C., Schieber, A. and Carle, R. (2001) Phytochemical and Nutritional Significance of Cactus Pear. European Food Research and Technology, 212, 396-407. https://doi.org/10.1007/s002170000219

[18] De Oliveira Ribeiro, E.M., Da Silva, N.H., De Lima Filho, J.L., De Brito, J.Z. and Da Paz Carvalho da Silva, M. (2010) Study of Carbohydrates Present in the Cladodes of Opuntia ficus-indica (Fodder Palm), According to Age and Season. Food Science and Technology, 30, 933-939. https://doi.org/10.1590/S0101-20612010000400015

[19] Goycoolea, F.M. and Cárdenas, A. (2003) Pectins from Opuntia spp.: A Short Review. Journal of the Professional Association for Cactus Development, 5, 17-29.

[20] Madjdoub, H., Roudesli, S., Picton, L., Le Cerf, D., Muller, G. and Grisel, M. (2001) Prickly Pear Nopals Pectin from Opuntia ficus Indica. Physicochemical Study in Dilute and Semidilute Solutions. Carbohydrate Polymers, 46, 69-79. 
https://doi.org/10.1016/S0144-8617(00)00284-8

[21] Espino-Díaz, M., De Jesús Ornelas-Paz, J., Martínez-Téllez, M.A., et al. (2010) Development and Characterization of Edible Films Based on Mucilage of Opuntia ficus-indica (L.). Journal of Food Science, 75, 347-352. https://doi.org/10.1111/j.1750-3841.2010.01661.x

[22] Lecaros, M. (1997) Caracterizacion De Harina De Cladodio De Nopal (Opuntia ficus indica). Memoria para optar al titulo de Ingeniero Agronomo, Universidad de Chile, Facultad de Ciencias Agronomicas, Santiago, 61 p.

[23] Boutakiout, A., Elothmani, D., Hanine, H., Mostafa, M., Le Meurlay, D. and Hmid, I. (2018) Effects of Different Harvesting Seasons on Antioxidant Activity and Phenolic Content of Prickly Pear Cladode Juice. Journal of the Saudi Society of Agricultural Sciences, 17, 471-480. https://doi.org/10.1016/j.jssas.2016.11.005

[24] Bensadòn, S., Hervet-Hernàndez, D., Sàyago-Ayerdi, S. and Goni, I. (2010) By-Products of Opuntia ficus-indica as Sources of Antioxidant Dietary Fiber. Plant Foods for Human Nutrition, 65, 210-216.

https://doi.org/10.1007/s11130-010-0176-2

[25] Do Nascimiento, T., Damilano, E., Gomes, A., Bezerra, F.C., Rodrigues, R.F., Cordeiro, D., et al. (2016) Potential for Biofuels from the Biomass of Prickly Pear Cladodes: Challenges for Bioethanol and Biogas Production in Dry Areas. Biomass Bioenergy, 85, 215-222. https://doi.org/10.1016/j.biombioe.2015.12.005

[26] Dick, M., Magro, L.D., Rodrigues, R.C., De Oliveira Rios, A. and Hickmann Flôres, S. (2019) Valorization of Opuntia monacantha (Willd.) Haw. Cladodes to Obtain a Mucilage with Hydrocolloid Features: Physicochemical and Functional Performance. International Journal of Biological Macromolecules, 123, 900-909. https://doi.org/10.1016/j.ijbiomac.2018.11.126

[27] Dick, M., Limberger, C., Silveira Thys, R.C., De Oliveira Rios, A. and Hickmann Flôres, S. (2020) Mucilage and Cladode Flour from Cactus (Opuntia monacantha) as Alternative Ingredients in Gluten-Free Crackers. Food Chemistry, 314, Article ID: 126178. https://doi.org/10.1016/j.foodchem.2020.126178

[28] Ginestra, G., Parker, M.L., Bennett, R.N., Robertson, J., Mandalari, G., Narbad, A., et al. (2009) Anatomical, Chemical, and Biochemical Characterization of Cladodes from Prickly Pear (Opuntia ficus-indica (L.) Mill.). Journal of Agricultural and Food Chemistry, 57, 10323-10330. https://doi.org/10.1021/jf9022096

[29] Hajslova, J., et al. (2011) Challenging Applications Offered by Direct Analysis in Real Time (DART) in Food-Quality and Safety Analysis. Trends in Analytical Chemistry, 30, 204-218. https://doi.org/10.1016/j.trac.2010.11.001

[30] Gross, J.H. (2014) Direct Analysis in Real Time-A Critical Review on DART-MS. Analytical and Bioanalytical Chemistry, 406, 63-80. https://doi.org/10.1007/s00216-013-7316-0

[31] Ma, H., Jiang, Q., Dai, D., Li, H., Bi, W. and Che, D.D.Y. (2018) Direct Analysis in Real Time Mass Spectrometry for Characterization of Large Saccharides. Analytical Chemistry, 90, 3628-3636. https://doi.org/10.1021/acs.analchem.8b00242

[32] Yew, J.Y. (2019) Natural Product Discovery by Direct Analysis in Real Time Mass Spectrometry. Mass Spectrometry, 8, 1-8. https://doi.org/10.5702/massspectrometry.S0081

[33] Wang, Y., Liu, L., Ma, L. and Liu, S. (2014) Identification of Saccharides by Using Direct Analysis in Real Time (DART) Mass Spectrometry. International Journal of Mass Spectrometry, 357, 51-57. https://doi.org/10.1016/j.ijms.2013.09.008

[34] Yang, H., Gao, G., Wang, Y., Liu, J., Li, Z., Su, R., et al. (2017) Ionization Characte- 
ristics of Glycosides by Direct Analysis in Real Time Quadrupole-Time of Flight Mass Spectrometry. New Journal of Chemistry, 41, 1103-1109. https://doi.org/10.1039/C6NJ02683D

[35] Huang, Y., Huang, Z., Watanabe, C. and Wang, L. (2019) Combined Direct Analysis in Real-Time Mass Spectrometry (DART-MS) with Analytical Pyrolysis for Characterization of Chinese Crude Propolis. Journal of Analytical and Applied Pyrolysis, 137, 227-236. https://doi.org/10.1016/j.jaap.2018.11.030

[36] Zeng, S., Wang, L., Chen, T., Wang, Y., Mo, H. and Qu, H. (2012) Direct Analysis in Real Time Mass Spectrometry and Multivariate Data Analysis: A Novel Approach to Rapid Identification of Analytical Markers for Quality Control of Traditional Chinese Medicine Preparation. Analytica Chimica Acta, 733, 38-47.

https://doi.org/10.1016/j.aca.2012.04.025

[37] Del Valle, V., Hernández-Muñoz, P., Guarda, A. and Galotto, M. (2005) Development of a Cactus-Mucilage Edible Coating (Opuntia ficus-indica) and Its Application to Extend Strawberry (Fragaria ananassa) Shelf-Life. Food Chemistry, 91, 751-756. https://doi.org/10.1016/j.foodchem.2004.07.002

[38] González Sandoval, D.C., Luna Sosa, B., Guadalupe Martínez-Ávila, G.C., Rodríguez Fuentes, H., Avendaño Abarca, V.H. and Rojas, R. (2019) Formulation and Characterization of Edible Films Based on Organic Mucilage from Mexican Opuntia ficus-indica. Coatings, 9, 506. https://doi.org/10.3390/coatings9080506

[39] Otálora, M.C., Carriazo, J.G., Iturriaga, L., et al. (2015) Microencapsulation of Betalains Obtained from Cactus Fruit (Opuntia ficus-indica) by Spray Drying Using Cactus Cladode Mucilage and Maltodextrin as Encapsulating Agents. Food Chemistry, 187, 174-181. https://doi.org/10.1016/j.foodchem.2015.04.090

[40] Gutiérrez, M.C., Utrilla-Coello, R.G. and Soto-Castro, D. (2018) Effect of Opuntia ficus-indica Mucilage in the Ecological Extraction, Drying, and Storage of Eggplant Anthocyanins. Journal of Food Processing and Preservation, 42, 1343-1349. https://doi.org/10.1111/jfpp.13439

[41] Nharingo, T. and Moyo, M. (2016) Application of Opuntia ficus-indica in Bioremediation of Wastewaters. A Critical Review. Journal of Environmental Management, 166, 55-72. https://doi.org/10.1016/j.jenvman.2015.10.005

[42] Adjeroud, N., Elabbas, S., Merzouk, B., et al. (2018) Effect of Opuntia ficus-indica Mucilage on Copper Removal from Water by Electrocoagulation-Electroflotation Technique. Journal of Electroanalytical Chemistry, 811, 26-36. https://doi.org/10.1016/j.jelechem.2017.12.081

[43] Vecino, X., Devesa-Rey, R., de Lima Stebbins, D., et al. (2016) Evaluation of a Cactus Mucilage Biocomposite to Remove Total Arsenic from Water. Environmental Technology \& Innovation, 6, 69-79. https://doi.org/10.1016/j.eti.2016.07.001

[44] Asha, S., Tabitha, C., Himabindu, N. and Kumar, R.B. (2014) Efficiency of Opuntia ficus-indica (L) Mill. in Removal of Chromium from Synthetic Solution. Research Journal of Pharmaceutical, Biological and Chemical Sciences, 5, 1244-1251.

[45] Chowdhury, M., Sengupta, A., Datta, L. and Chatterjee, S. (2017) Role of Mucilage as Pharmaceutical Additives and Cytoprotective Agent. Journal of Innovations in Pharmaceutical and Biological Sciences, 4, 46-52.

[46] Persia, F., Alisi, C., Bacchetta, L., Bojorquez, E., Colantonio, C., Falconieri, M., Insaurralde, M., Meza Orozco, A., Sprocati, A.R. and Tatì, A. (2016) Nopal as Organic Additive for Bio-Compatible and Eco-Sustainable Lime Mortars. 7 th Conference Diagnosis, Conservation and Valorization of Cultural Heritage, Naples, 15-16 December 2016, 245-251. 
[47] Honarmand, E., Mostaanzadeh, H., Motaghedifard, M., Hadi, M. and Khayadkashani, M. (2017) Inhibition Effect of Opuntia Stem Extract on Corrosion of Mild Steel: A Quantum Computational Assisted Electrochemical Study to Determine the Most Effective Components in Inhibition. Protection of Metals and Physical Chemistry of Surfaces, 53, 560-572. https://doi.org/10.1134/S207020511703008X

[48] Molina, M.W., Torres-Acosta, A.A., Martínez-Peña's, G.E.I. and Alonso-Guzman, E.M. (2014) Cement-Based Materials Enhanced Durability from Opuntia Ficus-Indica Mucilage Additions. ACI Materials Journal, 112, 165-172.

https://doi.org/10.14359/51687225

[49] Muñoz Bojorges, J.C., Quintero Lizaola, R., Pérez Nieto, J., Valdés Velarde, E., García Favela, B. and Rojas Acosta, M. (2015) Comportamiento de la actividad enzimatica del suelo al aplicar mucílago de nopal (Opuntia spp.). Terra Latinoamericana, 33, 161-167.

[50] Ciriminna, R., Chavarría-Hernández, N., Rodríguez Hernández, A.I. and Pagliaroa, M. (2018) Toward Unfolding Bioeconomy of Nopal (Opuntia spp.). https://doi.org/10.31226/osf.io/c89h3

[51] Prasertsan, P., Prasertsan, S. and H-Kittikun, A. (2011) Biotechnology Vol. X Recycling of Agro-Industrial Wastes through Cleaner Technology. Encyclopedia of Life Support Systems (EOLSS) UNESCO. 